\title{
Study drugs som vennetjeneste, ordineret medicin, eller stoffer til salg
}

Om anskaffelsen og brugen af ADHD lagemidler til optimering

\section{Margit Anne Petersen}

Institut for Marketing og Management, SDU margit@sam.sdu.dk

Petersen, Margit Anne (2018). 'Study drugs som vennetjeneste, ordineret medicin, eller stoffer til salg: Om anskaffelsen og brugen af ADHD lægemidler til optimering' i Tidsskrift for Forskning i Sygdom og Samfund, nr. 28, 133-153.

Denne artikel er baseret på etnografisk feltarbejde blandt studerende som tager ADHD lagemidler som optimering - også kaldet study drugs. Artiklen fokuserer specifikt på, hoordan study drugs bliver tilgængelige for de studerende. Det empiriske materiale viser, at der er tre primære måder at få fat $i$ study drugs på; som vennetjeneste, som ordineret medicin og som stoffer til salg. Ved at dykke ned i hvordan studerende opsøger disse study drugs bliver det tydeligt, at de forskellige markeder for study drugs ikke blot er måder at anskaffe sig medicin til optimering på, men i høj grad er udtryk for den moral, der forbindes med denne optimeringspraksis. Teoretisk diskuterer artiklen brugen af study drugs som en optimeringsteknologi, der på mange måder er forbundet med det moderne samfund og neoliberale værdier. Samtidig viser artiklen også, at der er begrænsninger ved denne type analyse, og at ved at fokusere på moral bliver det tydeligt, at studerende samtidigt både kan orientere sig med og imod de neoliberale vardier. 
Markets for Prescription Stimulants; Doctors, Dealers and Daily peers.

The use of ADHD medication for enhancement purposes among student populations is by now a well-known phenomenon, particularly in North America but by now also in many other parts of the world. However, we lack knowledge about how these prescription stimulants become accessible to students and therefore the aim of this article is to shed light on how students gain access to study drugs. The article is based on ethnographic fieldwork conducted in New York City and Copenhagen among a total of 30 students, as well as study counselors, university teachers, psychiatrists, drug dealers and the police. The empirical material suggests three main markets for study drugs, namely, through daily peers, doctors and dealers. The analysis shows that there are different moral dilemmas connected to the different ways of accessing study drugs, but that it is not the drug as such that is the object of moral negotiation but rather the way of acquiring and using them. The study drug markets are thus an expression of which story the students want to tell about themselves, and which person they are or want to become in our contemporary consumer culture.

\section{Introduktion}

I de seneste årtier har forskere inden for sundheds- og samfundsvidenskaberne vist en stigende interesse for at undersøge brugen af lægemidler af såkaldt raske mennesker til hvad, der anses for at være ikke-sygdomstilstande. Brugen af 'study drugs' er netop et af de store fokuspunkter i denne forskning, særligt i Nordamerika, hvor man primært har fokuseret på, hvor udbredt brugen af 'study drugs' er blandt universitetsstuderende på forskellige campusser (McCabe, West, Teter, \& Boyd, 2014). Begrebet 'study drugs' dækker oftest over ADHD lægemidler samt narkolepsi medicin (Ritalin, Adderall, Dexedrine og Modafinil) brugt af studerende i såvel gymnasiet som universitetet til at optimere deres studie-evner, oftest forstået som koncentration, udholdenhed og hukommelse (Teter, McCabe, LaGrange, Cranford, \& Boyd, 2006; Upadhyaya et al., 2010). I danske sammenhænge bruges begrebet i nogle tilfælde lidt bredere og inkluderer således også betablokkere, koffeinpiller og andre former for opkvikkende substanser (DJØF, 2015, 2017; Lyngsø-Dahl, 2016).

ADHD - og til dels narkolepsi-medicin tilhører den mest restriktive kategori af receptpligtige lægemidler, idet de aktive indholdsstoffer methylphenidat eller dexamfetamin er centralnervestimulerende og medvirker til at øge niveauet af dopamin og noradrenalin i kroppen ved at blokere re-absorptionen i de pre- 
synaptiske neuroner samtidigt med at frigivelsen af både dopamin, serotonin og noradrenalin øges (Jongh, Bolt, Schermer, \& Olivier, 2008; M. A. Petersen, 2015; Sundhedsstyrelsen, 2018). Disse kemiske forandringer i hjernen skulle eftersigende medvirke til at skabe en øget koncentrationsevne og en vis grad af energi eller opkvikkende effekt, men der hersker en del tvivl om de reelle kliniske effekter af medicinen både til personer med og uden ADHD (Lakhan \& Kirchgessner, 2012). Der rapporteres en del bivirkninger ved de forskellige præparater, hvoraf de mest almindelige så som søvnmangel og appetitmangel ofte forekommer at være de ønskede effekter blandt de studerende som bruger dem som study drugs (M. A. Petersen, 2015).

Spørgeskemaundersøgelserne i Nordamerika og enkelte europæiske lande har søgt at kortlægge brugen af study drugs baseret på demografiske mønstre så som etnisk baggrund, alder, køn og i nogle tilfælde sammenhænge mellem brugen af alkohol og stoffer generelt og brugen af study drugs (Castaldi et al., 2012; Franke et al., 2013; M. A. Petersen, 2015). Der findes indtil nu kun få studier, der undersøger brugen af study drugs kvalitativt, og dermed mangler der en del viden, om hvordan studerende oplever, bruger, udveksler og tænker om study drugs. Som de følgende eksempler peger på, nuancerer de få kvalitative undersøgelser, der foreligger, eksisterende forståelser af study drugs som fænomen. Scott Vrecko viser, baseret på et interview studie fra et amerikansk universitet, at de studerende bruger study drugs til at optimere deres energi, motivation og velbefindende (Vrecko, 2013). Hermed forstås det altså, at study drugs ikke udelukkende bruges som kognitiv, men i høj grad også som emotionel optimering. DeSantis og Hane har ligeledes interviewet studerende på én campus på USA's østkyst, og fokuserer på de studerendes manglende moralske skrupler i forbindelse med brugen af lægemidlerne til optimering (DeSantis \& Hane, 2010). Petersen har i sit etnografiske feltarbejde fulgt 20 studerende i New York og i første omgang fundet mange af de samme beskrivelser af brugen af study drugs samt legitimerende argumenter herfor blandt de studerende. Men det viser sig, at det at følge de studerende over et semesters tid giver et mere dybtgående og nuanceret billede af brugen af disse lægemidler, og i sin afhandling dokumenterer Petersen netop de moralske dilemmaer, der alligevel dukker op i forsøget på at jagte successen med at 'booste' selvet (Petersen 2015). Det kvalitative og særligt det etnografiske arbejde om study drugs er altså med til at frembringe vigtig ny viden om medicinsk optimering. Det giver især mulighed for at se på hvordan sådanne medicinske teknologier påvirker forståelser af selvet (Hogle, 2005; Pickersgill, 2015), samt anledning til at diskutere, hvorvidt det at ville forbedre selvet via lægemidler er et udtryk for neoliberale 
værdier om produktivitet og individets eget ansvar for succes (M. A. Petersen, Nørgaard, \& Traulsen, 2015).

Denne artikel fokuserer specifikt på, hvordan study drugs bliver tilgængelige for brug til optimering. Det empiriske materiale viser, at der er tre primære måder at få fat i study drugs på; som vennetjeneste, som ordineret medicin og som stoffer til salg. Ved at dykke ned i hvordan studerende opsøger disse study drugs, bliver det tydeligt, at de forskellige markeder for study drugs ikke blot er måder at anskaffe sig medicin til optimering på, men i høj grad udtryk for den brug og moral, der forbindes med denne optimeringspraksis. Artiklens sigte er altså at vise, at de moralske overvejelser, der knyttes til brugen af study drugs ikke handler om 'stofferne' selv, men om måden hvorpå man anskaffer sig dem og bruger dem på.

\section{At studere 'study drugs'}

Artiklen her er baseret på etnografisk feltarbejde udført i 2013 primært i New York, men også i København og omegn. Det empiriske materiale består af mere end 60 interviews samt 7 måneders deltager observation i og omkring 5 forskellige universiteter og deres dertilhørende studiemiljøer. Feltarbejdet blev udført som en del af et Ph.d. projekt, og enkelte dele af materialet i denne artikel optræder således også i afhandlingen.

Studerende, der har deltaget som informanter, blev fundet ved at de svarede på en 'e-mail-flyer', der beskrev projektet og blev sendt ud via adskillige mailinglister på to af universiteterne i New York. Derudover blev snebold-metoden anvendt, da samtlige informanter efter interviews blev spurgt om de kendte nogen, der ville deltage. I den danske del af feltarbejdet var rekrutteringsstrategien mere eller mindre den samme, bortset fra at 'flyeren' blev hængt op på adskillige opslagstavler på to forskellige campusser i København. Hvor de studerende i New York var meget ivrige for at deltage var det noget mere kompliceret i København. Der var kun én studerende der svarede på den danske 'flyer', og hun fortalte, at det var problematisk for hende at tage sedlen med kontakt informationen, da hun var bange for at blive set af andre på gangen. Jeg fandt flere danske informanter via mit eget netværks venner og bekendte, men generelt var de danske studerende meget bange for at blive opdaget og var derfor kun villige til at mødes på kirkegårde og andre afsides steder for at mindske risikoen for at medstuderende og andre bekendte skulle se dem. Enkelte var også bekymrede for politiet, fordi det handlede om ulovlig brug af receptpligtig medicin. 
I New York bestod feltarbejdet af møder med 20 studerende (14 mandlige og 6 kvindelige) fra BA til Ph.d. niveau samt nogle studievejledere, universitetslærere, politifolk og drug-dealere. I København var der 6 danske informanter fra BA til MA niveau (5 mandlige og 1 kvindelig), som brugte study drugs samt en lille gruppe af 6 udvekslingsstuderende fra USA, Canada og Australien, 7 studievejledere, 2 psykiatere og nogle politifolk. Forskellene imellem adgangen til informanterne i henholdsvis København og New York har været med til at pege på vigtigheden af de omkringliggende samfundsnormer, praksisser og regler $\mathrm{i}$ studiet af study drugs, og hertil hører blandt andet et fokus på, hvordan de studerende får fat i study drugs, og hvad det betyder for deres syn på brugen af dem. Det empiriske materiale der ligger til grund for denne artikel, er transskriberede interviews samt feltnoter, som er blevet gennemgået og kodet manuelt (Charmaz, 2014) med henblik på at se sammenhænge mellem anskaffelse og syn på study drugs. De teoretiske perspektiver, der ligger til grund for analysen, beror dels på begreber som 'medikalisering' og 'pharmaceutikalisering', der søger at redegøre for samfundsmæssige forandringer i hvordan og hvornår medicin bruges, både legalt og illegalt, (Bell \& Figert, 2012; Clarke, Shim, Mamo, Fosket, \& Fishman, 2010; Williams, Martin, \& Gabe, 2011) samt litteratur om selvet i en neoliberal kontekst (Elliot, 2003; Gershon, 2011; Martin, 2000; Rose, 2007), der konstant skal følge med i det den danske sociolog, Anders Petersen, kalder præstationssamfundet (A. Petersen, 2016). I denne sammenhæng viser artiklen, at det er relevant at se på, hvordan personlig moral forhandles og eksperimenteres med, i hverdagssituationer blandt studerende, der forsøger at gøre det godt, både fagligt og personligt. Fokus på de moralske forhandlinger er inspireret af Mattinglys begreb 'moralske laboratorier' beskrevet som forestillede sociale rum, der indeholder potentialer og muligheder for nutiden såvel som fremtiden (Mattingly, 2014). De måder, de studerende anskaffer sig study drugs på, og de overvejelser, der indgår i hvordan de vælger at bruge dem, giver altså et privilegeret indblik i moralske hverdagseksperimenter.

\section{Study drugs som vennetjeneste eller ordineret medicin}

Ved første møde fortæller Martin, en BA studerende i New York, at han netop har afleveret en opgave i antropologi, om hvor nemt det er at få fat i Adderall på universitets campus. Han bruger selv study drugs og kender mange, der også gør, men i forbindelse med sin opgave fremhæver han, at han gjorde en specifik indsats for at spørge folk udenfor hans sociale netværk, for at se hvor nemt det 
ville være at anskaffe udenfor vante kredse. På et par dage erfarede han, at 8 ud af 10 personer var klar til at give ham nogle af de små hvide eller blå piller, som så mange efterspørger - særligt i eksamensperioderne. "Jeg er ikke så overrasket for jeg kender jo godt studiekulturen her, men det var alligevel lidt nemmere end jeg lige havde regnet med... de gav mig det bare..." fortæller han.

I tråd med Scott Vrecko's undersøgelse fra et universitet på Amerikas østkyst (Vrecko, 2015) er de fleste studerende, som bruger study drugs i New York, også typisk en del af et socialt miljø, hvor man udveksler disse drugs, når man har nogle. Man skaffer som regel en eller to piller i forbindelse med en større aflevering eller eksamen, eller fordi man, som mange oplever det, bare har for mange ting, der skal gøres på for lidt tid. Nogle gange foregår udvekslingen af study drugs i faste sociale relationer, hvor studerende tilbringer studietid sammen i biblioteket og i den forbindelse deler disse drugs. Andre gange foregår det mere tilfældigt som beskrevet i forbindelse med Martins opgave. Mange bruger også sociale medier til at finde frem til hvem, der har ekstra piller på et givent tidspunkt. Dem, der deler ud af deres study drugs, får dem som regel på recept og har derfor rigelige mængder at give af. De fleste siger, at de kender nogen med recept, og at det er derigennem, de får study drugs, når de har behov for et ekstra boost. Men det sker også, at der ikke altid er tilgængelige study drugs, når man har brug for dem. Martin beskriver, hvordan han ved sidste eksamen ikke kunne få fat i nogle piller, og at det startede nogle tanker i retning af at prøve at få en recept, så han ikke længere skulle være afhængig af andre. Ben, en Ph.d. studerende ved samme universitet, blev også træt af at skulle bede om piller fra sine venner og bekendte, og han fik via universitets læge ordineret Adderall på trods af, at han ikke havde nogen diagnose. "Man siger bare at man har svært ved at koncentrere sig og så udskriver de medicinen. Det er meget nemt," fortæller Ben. De fleste er enige om, at det ingen sag er at få en læge overbevist, og at man ikke behøver at have ADHD for at kvalificere sig til en sådan recept (M. A. Petersen, Nørgaard, \& Traulsen, 2014; Vrecko, 2015). Universitetets rådgivningsafdeling sørger for at imødekomme studerende, der søger hjælp, hvis de ikke kan overkomme studierne. Deres plakater på gangene rundt omkring på campus viser et billede af en ung kvinde omgivet af stakkevis af bøger. Hun har tydeligvis hovedpine og er overvældet. Nedenunder står der spørgsmål som 'Har du svært ved at leve op til dit potentiale?' og 'Har du problemer med koncentrationen?'. Ben, Martin og en række andre informanter har gennem denne afdeling fået en henvisning til en psykiater, som har udskrevet Adderall uden større undersøgelse. Ben forklarer: 
"Jeg har en forsikring gennem universitet. Så først skal jeg tale med en terapeut som stiller nogle meget generelle spørgsmål, om hvorfor jeg synes, jeg har brug for medicin. Så henviser hun mig til en psykiater, og det er en legitim psykiater, men altså, det er lidt af en svingdør...folk valter ind og ud med samme xrinde som jeg. Det er lidt en joke. Psykiateren har nogle spørgsmål om symptomer på sådan nogle små indekskort. Og det er ikke engang fordi jeg finder på alle symptomerne, det er bare at symptomerne er så brede, at alle kan svare ja til dem."

Som det fremgår af Bens fortælling, foregår der hverken særlig meget rådgivning eller en egentlig helbredsundersøgelse i mødet med lægen. Og som Martin beskriver det, er det heller ikke, fordi man har brug for lægen til andet end at udskrive de piller, man gerne vil have. Martins proces med at anskaffe sig en recept på Adderall resulterede først i en recept på Klonopin, og dernæst benzodiazepin, fordi han svarede ja til nogen gange at have søvnproblemer. Derudover fik han en recept på Ritalin for at se, om det var nok til at hjælpe med koncentrationen, men da han ikke brød sig om effekten af Ritalin, tog han tilbage til lægen og sagde, at det ikke virkede, og fik derefter sin Adderall-recept. Netop denne villighed fra lægens side til at udskrive medicin til stort set hvad som helst og hvem som helst er, hvad der får Martin til at omtale lægen som 'intet andet end en pille-pusher'. Han forklarer, at han ikke stoler på lægen, fordi lægen ikke selv har prøvet medicinen.

"Det var virkelig langt ude fordi jeg fik både Klonopin og Adderall og så synes han at jeg også skulle have noget terapi. Og jeg tænkte bare, ja, hvis du både giver mig en 'downer' og noget 'speed' som jeg skal tage hver dag så fär jeg virkelig brug for terapi. Jeg har ret meget erfaring og jeg ved at de to drugs hver dag, det er ikke en god idé...det kan godt være at eksperterne ved en masse om selve kemien og sådan noget, men når det kommer til personlig erfaring og hoordan medicinen interagerer med min krop så tror jeg helt sikkert mere på mig selv." (Martin, BA studerende)

Disse indblik i relationen mellem lægen og de studerende, som vælger at bede om en recept på study drugs fremfor at skaffe dem illegalt fra gang til gang, peger på, hvad der omtales som en opløsning af grænsen mellem behandling og optimering (Coveney, 2012; Elliot, 2003; Møldrup \& Hansen, 2006; Møldrup, Traulsen, \& Almarsdottir, 2003; Morrison, 2008; M. A. Petersen, 2015; M. A. Petersen et al., 2014; Rasmussen, 2008). Når medicinen udskrives på recept, registreres det som behandling uanset om det er baseret på en diagnose eller udenfor indikation. Men 
der hersker ingen tvivl, om at mine informanter ikke opfatter sig selv som syge eller i behandling. Der er således heller ingen af dem, som følger lægens anvisning om at tage medicinen regelmæssigt. For dem er lægen en nem og legal adgang til study drugs og medicinen bruges udelukkende i situationer, hvor der er brug for et ekstra boost.

Nogle studerende havde allerede en recept fra deres tid i skolen og havde således allerede før universitetslivet adgang til study drugs. Harrison, en MA studerende med både fuldtidsstudier og fuldtidsarbejde, var blevet introduceret til study drugs i 14-15 års alderen gennem sin far som selv bruger pillerne til at øge sin produktivitet og gerne ville have at hans søn skulle klare sig bedre i skolen. Josh, en BA studerende, har også en recept fra tidligere, som han stadig drager nytte af. Oprindeligt blev han ordineret anti-depressiv medicin af sin mors psykiater i et forsøg på at gøre en kompliceret familiesituation mere tålelig for Josh $\mathrm{i}$ hverdagen, men for at kunne klare de mange bivirkninger fra anti-depressiverne, gav lægen ham også Adderall. Han bruger ikke længere anti-depressiv medicin, men er glad for stadig at have sin nemme adgang til Adderall. Amy, en første års BA studerende fortæller også, at hun prøvede study drugs første gang i teenageårene, og at der på hendes skole var mange, som fik det på recept og delte det med vennerne. Hun har aldrig selv haft behov for at få en recept, fordi hun, som hun siger, "kender virkelig mange der har adgang, så jeg får bare et par stykker når jeg har brug for det".

Som det fremgår af alle de empiriske eksempler, er det relativt nemt for studerende at få fat i study drugs på både legal og illegal vis. Dette nuancerer den eksisterende viden, særligt fra spørgeskemaundersøgelserne lavet i Nordamerika, der kalder brugen af study drugs for ikke-medicinsk brug af lægemidler og sætter lighedstegn mellem dette og både illegalt stof brug og stofmisbrug (Rabiner et al., 2009; Sepulveda et al., 2011; Teter et al., 2006; Upadhyaya et al., 2010). Forskere har et stykke tid peget på forbindelsen mellem de mange ADHD diagnoser og udbredelsen af ADHD medicinen til raske individer (DeSantis, Webb, \& Noar, 2008; Inciardi et al., 2009; McCabe et al., 2014; Poulin, 2001). En større amerikansk rapport viser også, at mens brugen af receptpligtig medicin i høj grad er steget blandt unge, så er brugen af illegale stoffer faldet tilsvarende (Johnston, O'Malley, Bachman, Schulenberg, \& Miech, 2013). Meget tyder således på, at receptpligtig medicin som den der bruges som study drugs, i mange tilfælde har overtaget pladsen for illegale substanser som for eksempel amfetamin, kokain og lignende stimulanser. Udbredelsen og brugen af medicin til optimeringsformål kan delvist forklares via begreber som medikalisering (Clarke et al., 2010; Conrad \& Potter, 
2000; Williams, Gabe, \& Davis, 2008) og 'pharmaceuticalization' (Coveney, Gabe, \& Williams, 2011; Williams et al., 2008; Williams et al., 2011), der peger på forandringer i sygdomsforståelser og medicinbrug, der gør, at vi i stigende grad forklarer tilstande og situationer som genstand for medicinsk eller farmakologisk intervention (M. A. Petersen, 2015). Dette hænger også sammen med udviklingen af optimeringsteknologier (Brogaard, Petersen, Grue, \& Fihl, 2015; Hogle, 2005; M. A. Petersen, 2015; M. A. Petersen et al., 2014; Rasmussen, 2008), som på lignende vis peger på en generelt mindre accept af menneskelige begrænsninger og en drivkraft, der styrer hen imod at øge kontrollen over menneskets biologi (Rose, 2007) . Den nemme adgang studerende har til study drugs, handler således ikke kun om unges vaner og behov, men i høj grad også om hvordan medicinens og særligt lægemidlernes rolle i samfundet har ændret sig, og om hvordan det nok især i USA, og til dels også i Europa, er blevet mere eller mindre normalt at rykke ved grænserne for hvad man som person skal kunne eller være (Elliot, 2003; Rose, 2007).

\section{Study drugs som stoffer til salg}

Det er langt fra alle study drugs, der gives som vennetjenester eller ordineret medicin. Der findes både online og offline sorte markeder, hvor ikke kun study drugs, men adskillige andre receptpligtige lægemidler samt et hav af illegale stoffer, købes og sælges. Et af de mere kendte online eksempler er 'Silk Road', en decideret virtuel markedsplads man kun kan komme ind på via særlige torbrowsere (Hout \& Bingham, 2013a, 2013b), men der findes også adskillige 'almindelige' hjemmesider, som sælger receptpligtig medicin til folk uden recepter. Gideon, en MA studerende i Danmark, har ofte købt sine study drugs via Silk Road, når han ikke har kunne skaffe dem via sin ven med ADHD. Marc, en BA studerende ved et andet universitet i Danmark køber altid sine study drugs via en af disse 'almindelige' hjemmesider. Gideon køber altid indenfor EU, da han har fundet ud af, at det er sikrest - både $\mathrm{i}$ forhold til om varerne når frem og i forhold til eventuelt at blive opdaget. "Myndighederne tjekker ikke posten, når den kommer fra EU lande," fortæller han. Marc får sine study drugs fra Indien, men får en ven til at modtage pakken også indenfor EU, og får dem sendt videre derfra til Danmark.

Ingen af mine informanter i New York købte study drugs for penge, hverken på nettet eller via en person i deres netværk. Der var dog meget synligt study drugs til salg i et online magasin, som svarer lidt til Den Blå Avis i Danmark. Adskillige 
annoncer for 'studiehjælp' florerede på siderne og efter mange forgæves forsøg, lykkedes det at etablere kontakt med nogle af dem som solgte denne 'studiehjælp'. De fleste af dem solgte en række lægemidler, men det var tydeligt, at det var Adderall og lignende præparater, der var i høj kurs. Darren, en af sælgerne, solgte de lægemidler, han selv fik på recept, blandt andet Ambien, et sovemiddel, foruden Adderall. Han fik mere medicin, end han havde lyst til at tage, og solgte derfor resten for at tjene lidt ekstra. John, en anden sælger, ville ikke afsløre detaljer omkring sin adgang til de lægemidler, han solgte, men forklarede alligevel i generelle træk: "Jeg har en forbindelse til nogen inden for medicin og sælger ofte flere hundrede piller om måneden". John var også betydeligt sværere at få i snak end de andre sælgere, hvilket nok i hvert fald delvist tyder på et stofsalg af større omfang. Samir, også en sælger med en annonce for studiehjælp, havde tidligere solgt lægemidler og illegale stoffer af forskellige slags, men havde tilbragt noget tid i fængsel og var blevet lidt mere forsigtig. Han solgte recepter - eller rettere adgang til recepter.

\begin{abstract}
"Jeg kender til en læge, som ikke har noget imod at udskrive Adderall og andre slags lægemidler. Jeg hjælper folk - primært advokater og folk $i$ finansverdenenoftest med at få en recept på fx Adderall. Jeg fortzller dem, hvad de skal gøre, og hvad de skal sige til lægen, og følger dem derhen og sådan noget...og så betaler de mig 200 dollars." (Samir, sælger).
\end{abstract}

Jeg spørger Samir, om han slet ikke sælger til studerende, hvortil han svarer, som om det er en selvfølge, at når det er så nemt for studerende at få fat i study drugs, så behøver de ikke købe det - og slet ikke gennem en annonce. Der er heller ingen af de tre sælgere, her beskrevet, som er studerende på trods af at de annoncerer deres piller til salg som studiehjælp. Under feltarbejdet nævner jeg for samtlige informanter, at jeg har set en del annoncer for Adderall til salg. De er hver især overraskede og tager afstand fra ideen om at nogen faktisk køber dem på den måde. Når jeg spørger ind til det, får jeg svar som at 'det er for risikabelt at købe på den måde' eller 'det er nok meget dyrt' eller 'hvem ved, hoad det er for nogle folk, og hoad de egentlig sælger'. Disse bekymringer eller skeptiske udsagn er på mange måder parallelle til Jakob Demants beskrivelse af danske unges overvejelser vedrørende køb af illegale stoffer i nattelivet fra personer, de ikke kender - også kaldet det offentlige marked (Demant, 2010). Der er i det hele taget mange ligheder mellem anskaffelsen af study drugs og anskaffelsen af stoffer i nattelivet, særligt hvad angår vigtigheden af de venskabsrelationer, som karakteriserer en stor del af stofmarke$\operatorname{det}$ (Demant, 2010; Jarvinen, 2010). For at kunne beskrive disse relationer nærmere 
karakteriserer Demant stofmarkedet via termerne 'det offentlige, det halvoffentlige og det private marked' (Demant, 2010). Det er tydeligt, at anskaffelsen og udvekslingen af study drugs blandt de studerende i New York primært foregår via det private marked. De fleste studerende betaler aldrig for deres study drugs, men får dem, som beskrevet, af venner og bekendte. De, der betaler for dem, får dem på recept og betaler således et lille, næsten symbolsk beløb til det apotek, hvor pillerne hentes. Ben, som får Adderall på recept, fortæller, at han aldrig kunne drømme om at tage penge for Adderall. Han deler hellere sine piller med nogle faste studiekammerater, som han tilbringer dage og nætter med på biblioteket når de har travlt med opgaver. "Det er rart at have nogle medsammensvorne", siger han, og omtaler særligt to venner som hans 'partners in crime'. David, en MA studerende, deler lejlighed med en fyr, som har adskillige recepter. David fortæller, hvordan han altid får en lille håndfuld hver gang fyren har fået fornyet sin recept uden at skulle bede om det. I tråd med Bens udsagn, mener David også, at det handler om at ville dele oplevelserne med nogen. "Det virker som om, han godt kan lide, at vi begge tager dem, og at vi kan relatere til den intense følelse, det er. Jeg tror, det er derfor, han bare giver mig dem," fortæller David.

Debbie, en MA studerende ved samme universitet har ikke selv en recept, men opsøger netop venner med adgang til Adderall, når hun står overfor store arbejdsbyrder på studiet.

"Jeg har overvejet, om jeg skulle fä min egen recept, men det føles lidt for meget som stofmisbrug, synes jeg. Altså, jeg har jo ikke brug for 100 Adderall. Jeg skal bare bruge et par stykker her og der. Det er nok bare min egen personlige grænse, det føles i hvert fald, som om jeg ville gå over stregen, hvis jeg gjorde det." (Debbie, MA studerende).

Debbie er langt fra den eneste, som synes, det er for langt at gå, at få en recept på Adderall. For nogle handler det, om ikke selv at ville anskaffe sig study drugs, men blot holde det på et niveau, hvor de får hjælp af en ven en gang i mellem eller blot er tilstede i situationer hvor study drugs bruges, så de bliver tilbudt uden at skulle spørge (Demant, 2010; Vrecko, 2015). For andre handler det om at begrænse sit forbrug af study drugs og sit begær efter den følelse, det giver at tage dem, som Davids beskrivelse her bevidner om:

"Det var lige før, jeg gik efter at få min egen recept, men...en af grundene til, at jeg ikke har gjort det, er, at jeg tror det vil være en glidebane for mig. Jeg tror, jeg 
vil have lyst til den der folelse af... af nye tanker... energi, fokus og produktivitet hele tiden...jeg tror, jeg ville komme til at overbruge det." (David, MA studerende).

Fælles for dem, som vælger kun at få study drugs som vennetjeneste frem for på recept eller ved at købe på nettet, er, at de via anskaffelsesmetoden skruer ned for forbruget. Anskaffelsesmetoden er således ikke kun et spørgsmål om at få fat i study drugs, men også et spørgsmål om hvor meget man får fat i via den pågældende anskaffelsesmåde. Samtidigt er det tydeligt at de forskellige anskaffelsesmetoder bringer nogle moralske overvejelser frem, som jeg vil komme nærmere ind på i næste afsnit.

\section{Moralske markeder}

Brugen af study drugs bliver ofte forbundet med neoliberale idealer og samfundstendenser hvor det drejer sig om at klare sig godt, være produktiv og i sidste ende stå til ansvar for sig selv og sit eget liv (Brogaard et al., 2015; M. A. Petersen, 2015). Det neoliberale samfund karakteriseres netop ved velfærdinstitutionernes mindskede rolle og en forståelse af selvet som et projekt eller en virksomhed, der konstant skal investeres i, arbejdes på eller udvikles (Martin, 2000). Selvet bliver derved til et slags katalog bestående af en række evner og egenskaber, som kan 'sælges' på markedet (Gershon, 2011; Martin, 2000). Gershon er som udgangspunkt kritisk overfor det neoliberale som analytisk tilgang, idet hun påpeger vigtige begrænsninger $\mathrm{i}$ forhold til at forstå sociale og epistemologiske forskelle (Gershon, 2011), men hun viser, hvordan vi under neoliberale termer alligevel kan forstå visse aspekter af selvet og dets relationer. Ifølge Gershon går det refleksive selv forud for relationer, og man må derved ifølge neoliberalismen forstå relationer som alliancer forbundet til markedslogik og markedsrationalitet (Gershon, 2011). Et langt stykke af vejen er det meget nærliggende at forstå brugen af study drugs som et forsøg på at leve op til og forfølge neoliberale værdier. De studerende beskriver ivrigt det eftertragtede 'tunnelsyn', 'produktive flow', og 'energi- og selvtillidsboost', som de får ud af at tage study drugs. De beskriver, hvordan de kan nå mere på kortere tid og får bedre arbejdsvaner med study drugs (M. A. Petersen et al., 2015). Men disse bevidste valg og idealer om at gøre mere og klare sig godt, som karakteriserer tilslutningen til det neoliberale, er kun en del af historien. Som de empiriske indblik i denne og andre artikler viser, er brugen af study drugs $i$ 
særdeleshed præget af moralske overvejelser i form af uklarhed (M. A. Petersen et al., 2015), ambivalens (M. A. Petersen et al., 2014), og legitimerende argumenter (DeSantis \& Hane, 2010; M. A. Petersen et al., 2014). Adskillige forskere peger på, hvordan medicinske teknologier netop påvirker og derved rykker ved normer og værdier (Elliot, 2003; Hogle, 2005; Lock, 2000) og hvordan ting, herunder teknologier, indeholder moral, idét de ved deres eksistens tvinger mennesker til at forholde sig til dem og tage beslutninger, som nødvendigvis er af moralsk karakter (Verbeek, 2011). Ud fra det empiriske materiale er det min overbevisning, at markeder tilsvarende kan indeholde moral, og dermed ikke blot er måder at anskaffe sig for eksempel study drugs på, men udtryk for moralske forståelser og værdier knyttet til denne praksis. I sit arbejde om afroamerikanske familier med handicappede børn viser Mattingly netop, hvordan moral primært kommer til udtryk og forhandles igennem hverdagslige situationer og handlinger (Mattingly, 2014). Spørgsmålet om, hvorvidt et barn i kørestol for eksempel skal deltage i fysisk krævende sportsaktiviteter, bliver således et moralsk laboratorium, hvor forældre forhandler mellem forskellige og nogle gange modsatrettede forestillinger om, hvad en god forælder er, samt hvad det gode liv kan være (Mattingly, 2014). Selvom der er langt fra 'Mattinglys familier til 'mine studerende', synes der at være nogle fælles træk i form af hverdagsligt moralsk arbejde forbundet med håb og forestillinger om potentielle muligheder for både væren og kunnen. Når studerende vælger at ville bruge study drugs på studiet, kommer deres moralske overvejelser frem netop via de måder, de anskaffer sig pillerne på. Det er altså i de hverdagslige valg og handlinger eller ikke-handlinger, som for eksempel ikke at ville bede om study drugs, men vente på at blive tilbudt dem, at vi kan spore hvilken historie om sig selv, de gerne vil fortælle både til sig selv og andre. Lad os tage et nærmere kig på hvad det er for overvejelser, der knytter sig til de forskellige måder at skaffe sig adgang til study drugs.

Study drugs som vennetjeneste karakteriseres ved, at man som tidligere vist enten giver eller modtager study drugs blandt venner eller bekendte, uden at der er penge involveret. Det er derfor et uformelt og privat marked, der bygger på relationer og fælles oplevelser. De studerende, som får study drugs på denne måde, fremhæver tit, at de bare skal have et par piller i ny og næ, som for eksempel Debbies udsagn vidner om, eller at de ikke selv kunne finde på at spørge efter study drugs, men ofte sørger for at være tilstede på de rigtige tidspunkter, som Vrecko for eksempel dokumenterer det (Vrecko, 2015). I begge tilfælde er der noget moralsk på spil, idét grænsen mellem hvad der anses for at være i orden og ikke i orden drages. Debbie vil gerne have et par piller, men ikke for mange. For hende 
er det kun acceptabelt, hvis omfanget og tilgængeligheden ikke er for stor. David ligeledes, og selvom han ikke behøver at gøre noget for at få fat i sine study drugs, fordi han bor sammen med en, som skaffer dem, så er der tydeligvis en forskel i hans bevidsthed mellem at få dem og selv at skulle skaffe dem. Davids udsagn, om at hans sambo gerne vil dele oplevelsen med ham, bevidner om, at der knyttes nogle særlige bånd og relationer mellem study drug brugere, hvilket også gør sig gældende for Ben, som synes, det er rart at have nogle 'medsammensvorne' i sin optimeringspraksis. David fortæller dog, at hans sambo bruger mange flere substanser end ham selv, og at han nogen gange sørger for ikke at være hjemme, når der er nye forsyninger som endnu en måde at begrænse sit eget forbrug på. Selvom dette private marked ikke er præget af egentlig økonomi, så synes der at være et vist omfang af udveksling i form af forpligtelse til netop at indvillige sig i det fælles univers, som study drug udvekslingen forudsætter. Det er måske særligt tydeligt i Davids tilfælde, men også i Bens udsagn ligger der en implicit forventning om, at hans studiekammerater møder op, er faste studie-partnere og tager del i den risiko, som Ben og mange andre studerende i hvert fald til dels eropmærksomme på, at der kan være ved study drugs.

"Man behøver jo ikke se på det som et 'stof'. Det er et værktøj. Men ja, værktøjer kan være farlige, det kan alting jo, så man skal selvfølgelig være forsigtig." (Ben, Ph.d. studerende).

Ben fortæller ikke sin kæreste, som han bor sammen med, at han tager study drugs, netop fordi han ikke vil bekymre hende. Mange fortæller heller ikke deres forældre om det, fordi, som Debbie siger, "de ville blive virkelig skuffede over at jeg ikke kunne klare mig uden at snyde". Når jeg spørger til, om hun ser det som snyd at tage study drugs, fortæller hun, at der ikke er nogen regler på universitetet, som gør det til egentlig snyd, men at det alligevel ikke føles helt rigtigt at fortælle om til forældrene. Hendes kæreste holder hun det dog ikke hemmeligt for. Uanset hvordan det forholder sig i de enkelte tilfælde, er de fleste enige om, at der er en form for risiko ved at tage study drugs, men at det er en risiko, de fleste er villige til at løbe, hvis de oplever, at de får nok ud af det. Denne form for benefit-risk calcule er ifølge Gershon helt karakteristisk ved det neoliberale i og med at succes netop forbindes med risici (Gershon, 2011). Det interessante her er at det bliver et moralsk anliggende at finde den rigtige balance mellem risiko og sikkerhed i forsøget på at optimere selvet, en balance, som netop er et spørgsmål om relationen mellem erfaring og eksperiment (Mattingly, 2014). 
De studerende, som vælger at skaffe study drugs via egen recept, bringer nogle andre moralske overvejelser frem. Som tidligere vist mener de ikke, at de har ADHD eller et egentligt medicinsk behov for behandling. Men flere af dem legitimerer deres recept, med at lægen faktisk har udskrevet medicinen, og at det derfor er i orden at tage dem. Både Ben og Martin fortæller hver især, at de ikke decideret har løjet om symptomerne hos lægen, men at stort set alle kan kvalificere sig til en sådan recept. Med andre ord så legitimerer de deres brug af Adderall eller Ritalin med ADHD diagnosens diffuse og udbredte karakter (M. A. Petersen et al., 2014). Flere studerende nævner faktisk, at når så mange folk får diagnosen og tager medicinen hver dag, så kan det ikke skade at tage den en gang i mellem som study drugs. Netop alle disse legitimerende argumenter bevidner om en form for moralsk uklarhed eller ambivalens, både i relation til lægerne og sundhedssystemet og i relation til medicinen som optimeringspraksis (M. A. Petersen et al., 2014). Vælger man at få medicinen via lægen, skal man til en vis grad være villig til at tale sig ind i en verden af symptomer og problemer, og det er måske en af de vigtigste moralske forskelle mellem at få study drugs som vennetjeneste og som ordineret medicin.

Selvom study drugs til salg er et stort og offentligt marked, er det interessant at bemærke, at de studerende i denne undersøgelse i New York ikke benytter dette marked som adgang til study drugs. Det er måske ikke så overraskende, at når der er så mange study drugs i omløb på campusser og blandt venner og bekendte, så bliver det offentlige marked mindre relevant. Men udover ikke at benytte dette marked, så havde samtlige studerende noget imod at give eller tage penge for study drugs. Det er ikke noget, de ville begive sig ud i. Mange insinuerer, at det bliver for 'drug-agtigt', 'at så vigtigt er det heller ikke' og som tidligere fremhævet, så påpeger de usikkerheden ved at købe noget fra tilfældige. Som Ben siger, så behøver man ikke tænke på Adderall som et stof, men nærmere som et værktøj. Flere af de studerende betegner netop study drugs som et værktøj eller et redskab sammenligneligt med en god computer eller en stærk kop kaffe, vitaminer, kosttilskud og lignende, som også bruges i hverdagen. Mange nævner også, at de ikke tager study drugs for rusens skyld.

"Jeg tager jo ikke Adderall for at blive høj. Jeg tager det, fordi jeg gerne vil nå nogle ting, gøre nogle ting, fremfor bare at ligge på sofaen og slappe af." (David, MA studerende). 
At Adderall ikke opfattes som et 'stof', understøttes også af DeSantis og Hanes studie, som netop viser, at et af de legitimerende argumenter, studerende bruger i forbindelse med study drugs, er, at lægemidler er sikrere end illegale stoffer (DeSantis \& Hane, 2010). I tråd med dette kalder de studerende ikke Adderall 'et stof', når det bruges til fornuftige formål så som at studere bedre (M. A. Petersen et al., 2014). Det er altså ikke selve stoffet, men formålet og anskaffelsen af stoffet, som har en moralsk betydning. At de danske studerende primært anskaffer sig study drugs via internettets sorte marked, og af og til gennem venner med ADHD, når det kan lade sig gøre, bevidner om, hvor forskellig tilgængeligheden er. I København er det slet ikke så nemt at finde study drugs blandt venner, og det er heller ikke noget, man fortæller om til alle og en hver. Flere af de danske studerende nævner, at de holder det for sig selv, og at de har mærket negative reaktioner, hvis de har forsøgt at fortælle om det.

\begin{abstract}
"Jeg har lært af mine fejl. Jeg fortæller ikke længere bekendte om min brug af study drugs. De misforstår det, eller synes bare det er langt ude." (Gideon, MA studerende).
\end{abstract}

Som beskrevet i starten af artiklen var det langt fra nemt at finde danske studerende, der ville deltage i studiet af study drugs og tale om deres brug af disse, hvorimod det i New York var et meget nemt og tilgængeligt emne. At der er så store forskelle i tilgængelighed og måder at anskaffe sig study drugs på giver et privilegeret blik ind i, hvordan tilgængelighed, anskaffelse og moral hænger tæt sammen. Som Mattingly viser, er personlig moral tæet forbundet til tid og sted og altså ikke blot et udtryk for personlig overbevisning, men bør forstås som en udvikling over tid i relation til omkringliggende normer og praksisser (Mattingly, 2014). At vælge at anskaffe sig og bruge study drugs i studielivet udgør altså en form for moralsk laboratorium, hvori forhandlinger, om hvem man er, og hvordan man udlever og lever op til egne og andres krav, kommer til udtryk. Den måde, man opsøger study drugs på, er altså ikke blot en måde at anskaffe sig dem, men også et indblik i hvordan selvet forstås og forhandles gennem det at bruge study drugs enten som vennetjeneste, medicin eller stoffer til salg. 


\section{Konklusion}

Denne artikel har fokuseret på, hvordan studerende får fat i study drugs - ikke blot som en anskaffelsesmetode, men også som udtryk for hvordan disse lægemidler anskues og bruges. Det etnografiske feltarbejde viser tydeligt, at study drugs florerer i nogle sociale kredse i universitetsmiljøerne både i New York og København. Men det er ligeså tydeligt, at anskaffelsen af study drugs varierer indenfor og på tværs af disse kredse. De moralske overvejelser, der indgår i erhvervelsen af study drugs, er altså ikke blot et spørgsmål, om hvem man kender eller hvad de andre gør, men et spørgsmål, om hvad man som person kan stå inde for. At få study drugs gennem venner og bekendte er for mange en måde at begrænse brugen af study drugs på, ved ikke at have adgang til for mange study drugs ad gangen. Samtidig beror det på en fortælling - om ikke andet til dem selv - om at de ikke er afhængige af at have study drugs for at klare sig godt, men vælger at tage dem af og til, når det lige passer ind. At få dem på recept handler om at kunne regne med at have fast adgang til study drugs og kunne bruge dem, som man ønsker at planlægge det. Det handler også om at være den, der skaber et miljø omkring sig, og få andre med via sin adgang. Og dem, der vælger at gå efter en recept, bruger tit det, at lægen har sagt god for det, som legitimerende argument. At anskaffe sig study drugs via køb og salg synes primært at foregå blandt dem, der ikke har adgang til dem gennem deres omgangskreds, og ikke har lyst til at få dem gennem lægen. At bruge penge på study drugs opfattes af mange som moralsk forkert, fordi det forbindes med at være for desperat efter stoffer, og fordi det opfattes som mere risikabelt - både hvad angår kvaliteten af de piller, der sælges, samt illegaliteten ved køb og salg af receptpligtige lægemidler.

Disse meget forskellige og dog forbundne 'markeder' for study drugs bevidner for det første om, at der er mange moralske overvejelser forbundet med brugen af study drugs. Dernæst bliver det tydeligt, at det ikke er selve lægemidlet eller indholdsstoffet, de moralske overvejelser knyttes til, men nærmere anskaffelsen og brugen af disse. Der synes i nogle tilfælde at være en sammenhæng mellem de samfundsnormer og praksisser, der eksisterer i henholdsvist New York og København, hvor study drugs er meget mere udbredt og alment accepteret i New York end i København. Dette påvirker i høj grad, hvor nem adgang studerende har til study drugs, men det er også tydeligt, at nem adgang ikke nødvendigvis hænger sammen med hvad der synes rigtigt og forkert. Om forskellene mellem New York og København peger på større kultur- og samfundsforskelle i medicinbrug og forskellige forståelser af og måder at udleve selvet på, eller om disse forskelle også 
optræder internt inden for de to samfund, er ikke tydeligt ud fra nærværende studie. Det ville være et spændende område at udforske nærmere i forsøget på at komme dybere ned i, hvordan normer bliver til og kontinuerligt forhandles. Dette studie viser, at forskelle i de måder studerende anskaffer sig study drugs på, i høj grad kan kobles til moralske forhandlinger om hvem man som person er og vil være i det moderne forbrugssamfund. Spørgsmålet om, hvordan disse forestillinger om det gode liv bliver til, er stadig delvist åbent og ubesvaret.

\section{Referencer}

Bell, Susan E., \& Figert, Anne E. (2012). Medicalization and Pharmaceuticalization at the intersections: Looking backwards, sideways and forward. Social Science and Medicine, 75(5), 775-783. https://doi.org/10.1016/j.socscimed.2012.04.002.

Brogaard, Dorthe, Petersen, Margit Anne, Grue, Astrid, \& Fihl, Asger. (2015). Introduktion. Tidsskriftet Antropologi, Optimering(70).

Castaldi, Silvana, Gelatti, Umberto, Orizio, Grazia, Hartung, Uwe, Moreno-Londono, Ana Maria, Nobile, Marta, \& Schulz, Peter J. (2012). Use of Cognitive Enhancement Medication Among Northern Italian University Students. Journal of Addiction Medicine, 6(2), 112-117. https://doi.org/10.1097/ADM.0b013e3182479584.

Charmaz, Kathy. (2014). Constructing Grounded Theory (2nd edition ed.). London, Thousand Oaks, New Delhi, Singapore: SAGE Publications Ltd.

Clarke, Adele E., Shim, Janet K., Mamo, Laura, Fosket, Jennifer Ruth, \& Fishman, Jennifer R. (2010). Biomedicalization: A Theoretical and Substantive Introduction. In A. E. Clarke, L. Mamo, J. R. Fosket, J. R. Fishman \& J. K. Shim (Eds.), Biomedicalization. Technoscience, Health, and Illness in the U.S. (pp. 1-46). Durham \& London: Duke University Press.

Conrad, Peter, \& Potter, Deborah. (2000). From Hyperactive Children to ADHD Adults: Observations on the Expansion of Medical Categories. Social Problems, 47(4), 559-582. https://doi.org/10.2307/3097135.

Coveney, Catherine. (2012). Cognitive Enhancement? Exploring Modafinil Use in Social Context. In M. Pickersgill \& I. V. Keulen (Eds.), Sociological Reflections on the Neurosciences (Vol. Advances in Medical Sociology 13, pp. 203-228). Bingley: Emerald Group Publishing Limited.

Coveney, Catherine, Gabe, Jonathan, \& Williams, Simon. (2011). The Sociology of cognitive enhancement: Medicalisation and beyond. Health Sociology Review, 20(4), 381-393.https:// doi.org/10.5172/hesr.2011.20.4.381.

Demant, Jakob. (2010). Venner, købere og sælgere. In M. Jarvinen, J. Demant \& J. Østergaard (Eds.), Stoffer og natteliv (pp. 182-200). København: Hans Reitzels Forlag.

DeSantis, Alan D., \& Hane, Audrey Curtis. (2010). »Adderall is Definitely Not a Drug«: Justifications for the Illegal Use of ADHD Stimulants. Substance Use E Misuse, 45, 31-46. https://doi.org/10.3109/10826080902858334. 
DeSantis, Alan D., Webb, Elizabeth M., \& Noar, Seth M. (2008). Illicit use of prescription ADHD medications among college students: a multi-methodological approach. Journal of American College Health, 57(3), 315-324. https://doi.org/10.3200/JACH.57.3.315-324.

DJØF. (2015). Djøfs studielivsundersøgelse 2015: Danmarks Jurist og Økonomforbund.

DJØF. (2017). Djøfs studielivsundersøgelse 2017: Danmarks Jurist og Økonomforbund.

Elliot, Carl. (2003). Better than well - American medicine meets the american dream. New York and London: W.W. Norton and Company.

Franke, Andreas G., Bagusat, Christiana, Dietz, Pavel, Hoffmann, Isabell, Simon, Perikles, Ulrich, Rolf, \& Lieb, Klaus. (2013). Use of illicit and prescription drugs for cognitive or mood enhancement among surgeons. BMC Family Practice, 11(102). https://doi. org/10.1186/1741-7015-11-102.

Gershon, Ilana. (2011). »Neoliberal Agency«. Current Anthropology, 52(4), 537-555. https://doi. org/10.1086/660866.

Hogle, Linda F. (2005). Enhancement Technologies and the Body. Annual Review of Anthropology, 34, 695-716. https://doi.org/10.1146/annurev.anthro.33.070203.144020.

Hout, Marie Claire Van, \& Bingham, Tim. (2013a). 'Silk Road', the virtual drug marketplace: A single case study of user experiences. International Journal of Drug Policy, 24(5), 385-391. https://doi.org/10.1016/j.drugpo.2013.01.005.

Hout, Marie Claire Van, \& Bingham, Tim. (2013b). 'Surfing the Silk Road': A study of users' experiences. International Journal of Drug Policy, 24(6), 524-529. https://doi.org/10.1016/j. drugpo.2013.08.011.

Inciardi, James A., Surratt, Hilary L., Cicero, Theodore J., Kurtz, Steven P., Martin, Steven S., \& Parrino, Mark W. (2009). The »Black Box« of Prescription Drug Diversion. Journal of Addictive Diseases, 28(4), 332-347. https://doi.org/10.1080/10550880903182986.

Jarvinen, Margaretha. (2010). Indledning: Stoffer og natteliv. In M. Jarvinen, J. Demant \& J. Østergaard (Eds.), Stoffer og Natteliv (pp. 13-26). København: Hans Reitzels Forlag.

Johnston, Lloyd D., O'Malley, Patrick M., Bachman, Jerald G., Schulenberg, John E., \& Miech, Richard A. (2013). Monitoring the Future: National Survey Results on Drug Use, 1975-2013 (Vol. Volume 2, College Students and Adults ages 19-50). Ann Arbor, MI: Institute for Social Research, University of Michigan.

Jongh, Reinoud de, Bolt, Ineke, Schermer, Maartje, \& Olivier, Berend. (2008). Botox for the brain: enhancement of cognition, mood and pro-social behavior and blunting of unwanted memories. Neuroscience and Biobehavioral Reviews, 32(4), 760-776. https://doi. org/10.1016/j.neubiorev.2007.12.001.

Lakhan, Shahen E., \& Kirchgessner, Annette. (2012). Prescription stimulants in individuals with and without attention deficit hyperactivity disorder: misuse, cognitive impact, and adverse effects. Brain and Behavior, 2(5), 661-667. https://doi.org/10.1002/brb3.78.

Lock, Margaret. (2000). Accounting for disease and distress: morals of the normal and abnormal. In G. Albrecht, R. Fitzpatrick \& S. Scrimshaw (Eds.), Handbook of Social Studies of Health and Medicine (pp. 259-276). Thousand Oaks: Sage. https://doi. org/10.4135/9781848608412.n17.

Lyngsø-Dahl, Lars. (2016). Use of Prescription drugs for non-medical purposes - An accessibility perspective of study drugs in general practice. Master's thesis: University of Copenhagen.

Martin, Emily. (2000). Mind-Body Problems. American Ethnologist, 27(3), 569-590. doi: 10.1525/ae.2000.27.3.569 
Mattingly, Cheryl. (2014). Moral Laboratories: family peril and the struggle for a good life. Oakland, California University of California Press. https://doi.org/10.1525/california/9780520281196.001.0001.

McCabe, Sean Esteban, West, Brady T., Teter, Christian J., \& Boyd, Carol J. (2014). Trends in medical use, diversion, and nonmedical use of prescription medications among college students from 2003 to 2013: Connecting the dots. Addictive Behaviors, 39(7), 1176-1182. https://doi.org/10.1016/j.addbeh.2014.03.008.

Møldrup, Claus, \& Hansen, Rikke Rie. (2006). Public acceptance of drug use for nondiease conditions. Current Medical Research and Opinion, 22(4), 775-780. https://doi. org/10.1185/030079906X100258.

Møldrup, Claus, Traulsen, Janine M., \& Almarsdottir, Anna Birna. (2003). Medicallyenhanced normality: an alternative perspective on the use of medicines for nonmedical purposes. International Journal of Pharmacy Practice, 11(4), 243-249. https://doi. org/10.1211/0022357022683.

Morrison, Michael. (2008). Beyond the perils and promise of human enhancement: the social shaping of enhancement technologies. eSharp, issue 12: Technology and Humanity(winter), 1-24.

Petersen, Anders. (2016). Præstationssamfundet. Copenhagen: Hans Reitzels Forlag.

Petersen, Margit Anne. (2015). Governing Ambiguities - The Use of Prescription Stimulants among University Students in New York City. PhD thesis: University of Copenhagen.

Petersen, Margit Anne, Nørgaard, Lotte S., \& Traulsen, Janine M. (2014). Going to the Doctor with Enhancement in Mind - An ethnographic study of university students' use of prescription stimulants and their moral ambivalence. Drugs: Education, Prevention, and Policy.

Petersen, Margit Anne, Nørgaard, Lotte Stig, \& Traulsen, Janine. (2015). Pursuing Pleasures of Productivity: University students' Use of Prescription Stimulants for Enhancement and the Moral Uncertainty of Making Work Fun. Culture, Medicine \& Psychiatry, 39(4), 665-679. https://doi.org/10.1007/s11013-015-9457-4.

Pickersgill, Martyn \& Linda Hogle. (2015). Enhancement, ethics and society: towards an empirical research agenda for the medical humanities and social sciences. Medical Humanities, 41(2). https://doi.org/10.1136/medhum-2015-010718.

Poulin, Christiane. (2001). Medical and nonmedical stimulant use among adolescents: from sanctioned to unsanctioned use. Canadian Medical Association Journal, 165(8), 1039-1044.

Rabiner, David L., Anastopoulos, Arthur D., Costello, E. Jane, Hoyle, Rick H., McCabe, Sean Esteban, \& Scott, H. (2009). The Misuse and Diversion of Prescriped ADHD medications by College Students. Jounal of Attention Disorders, 13(2), 144-153. https://doi. org/10.1177/1087054708320414.

Rasmussen, Nicolas. (2008). On Speed: The many Lives of Amphetamine. New York and London: New York University Press.

Rose, NIkolas. (2007). The Politics of Life itself. Biomedicine, Power and Subjectivity in the 21st Century. Princeton, NJ: Princeton University Press. https://doi.org/10.1515/9781400827503.

Sepulveda, Dalissa R., Thomas, Lisl M., McCabe, Sean Esteban, Cranford, James A., Boyd, Carol J., \& Teter, Christian J. (2011). Misuse of Prescribed Stimulant Medication for ADHD and Associated Patterns of Substance Use: Preliminary Analysis Among College Students. Journal of Pharmacy Practice, 24(6), 551-560. https://doi. org/10.1177/0897190011426558. 
Sundhedsstyrelsen. (2018): https://http://www.sst.dk/da/rationel-farmakoterapi/praeparatanmeldelser/attentin-dexamfetamin.

Teter, Christian J., McCabe, Sean Esteban, LaGrange, Kristy, Cranford, James A., \& Boyd, Carol J. (2006). Illicit Use of Specific Prescription Stimulants Among College Students: Prevalence, Motives, and Routes of Administration. Pharmacotherapy, 26(10), 1501-1510. https://doi.org/10.1592/phco.26.10.1501.

Upadhyaya, Himanshu P., Kroutil, Larry A., Deas, Deborah, Durell, Todd M., Brunt, David L. Van, \& Novak, Scott P. (2010). Stimulant Formulation and Motivation for Nonmedical Use of Prescription Attention-Deficit/Hyperactivity Disorder Medications in a College-Aged Population. The American Journal on Addictions, 19(6), 569-577. https://doi. org/10.1111/j.1521-0391.2010.00078.x.

Verbeek, Peter-Paul. (2011). Moralizing Technology: Understanding and Designing the Morality of Things. Chicago and London: The University of Chicago Press. https://doi.org/10.7208/ chicago/9780226852904.001.0001.

Vrecko, Scott. (2013). Just how Cognitive is »Cognitive Enhancement«? On the Significance of Emotions in University Students' Experiences with Study Drugs. AJOB Neuroscience, 4(1), 4-12. https://doi.org/10.1080/21507740.2012.740141.

Vrecko, Scott. (2015). Everyday drug diversions: A qualitative study of the illicit exchange and non-medical use of prescription stimulants on a univeristy campus. Social Science and Medicine, 131(April), 297-304. https://doi.org/10.1016/j.socscimed.2014.10.016.

Williams, Simon J., Gabe, Jonathan, \& Davis, Peter. (2008). The Sociology of pharmaceuticals: progress and prospects. Sociology of Health $\mathcal{E}$ Illness, 30(6), 813-824. https://doi. org/10.1111/j.1467-9566.2008.01123.x.

Williams, Simon J., Martin, Paul, \& Gabe, Jonathan. (2011). The Pharmaceuticalisation of society? A framework for analysis. Sociology of Health \& Illness, 33(5), 710-725. https://doi. org/10.1111/j.1467-9566.2011.01320.x. 